\title{
QUALITY OF INFORMATION DISCLOSED IN INTEGRATED REPORTS, IN THE EXTRACTING SECTOR: INSIGHTS FROM EUROPE
}

\author{
Gianluca ZANELLATO* \\ Babes-Bolyai University, Romania
}

\begin{abstract}
The study explores to what extent are extracting organizations from the European region, disclosing relevant information about social and environmental practices. To pursue the current exploratory study, a qualitative approach composed of two steps is performed. The first is a content analysis of 15 oil \& gas and mining organizations integrated reports proposing a compliance exercise toward the International Integrated Reporting Framework. Then in the second one, the integrated reports of our sample are analyzed using MAXQDA, with the extent to which social and environmental references are positive, neutral, or negative. Thus, the present paper represents the first attempt in qualitative studies in Integrated Reporting with a specific focus on extracting sector. Our results demonstrate that the analyzed sample discloses more information related to the environment than social disclosure.
\end{abstract}

Keywords: Oil \& Gas, Integrated Reporting, Europe, Qualitative Content Analysis JEL classification: M40.

\section{Introduction}

The fast-economic development that occurred since the industrial revolution and the population growth can be considered responsible for the increase in greenhouse gas (GHG) emissions. Fossil fuels contributed with almost $80 \%$ of the total GHG released into our atmosphere from 1970 to 2010 , leading to the so-called phenomenon of global warming (IPCC, 2014).

Increased worldwide awareness about climate change, the global community agreed to adopt the Kyoto Protocol, from 1997, which aimed to introduce legally binding emission reduction targets for developed countries; and the Paris Agreement, from 2015, that sought to limit the global warming "well below" $2^{\circ} \mathrm{C}$ (ECCEU, 2017).

\footnotetext{
* Corresponding author. Address: Faculty of Economics and Business Administration, BabeșBolyai University, Cluj-Napoca, Romania, 400591 Th. Mihali Street 58-60, Tel. +40 264418655 , Fax.+40 264 412570, gianluca.zanellato@econ.ubbcluj.ro
} 
Consequently, firms worldwide began to consider their role in society and the environment; nowadays, non-financial reports such as Sustainability Reports (SR) are a normal characteristic in high profile businesses (Cho et al., 2015). Especially extractive industries, as the mining and oil \& gas industries, have been giving particular attention to Corporate Social Responsibility (CSR) and SR (Cowell et al., 1999; Guenther, 2007; Frynas, 2009; Spence, 2011). The extracting sector has the highest reporting rate compared to other industries (Halme \& Huse, 1997); as in these organizations, the environmental impact of their activity is significant (Ali \& O'Faircheallaigh, 2007).

Furthermore, other authors find that extracting companies disclose information about social and environmental aspects seeking approval from their stakeholders (Yongvanich \& Guthrie, 2005).

Therefore, extracting companies are embracing a relative new type of report which has been gaining momentum in the recent period: Integrated Reporting (IR); considered to be the evolution of the SR (Mio \& Fasan, 2016), it aims to include financial and non-financial information relevant to the company in a single connected report (Eccles R.G., Krzus M.P., 2010; Eccles R.G., Saltzman D., 2011; Paternostro S. 2016). According to the International Integrated Reporting Council (IIRC), IR aims to "promote a more cohesive and efficient approach to corporate reporting that draws on different reporting strands and communicates the full range of factors that materially affect the ability of an organization to create value over time" (IIRC, 2013; p. 2). Accordingly, longitudinal studies focusing on only one sector of activity are still scant and the use of the Integrated Reporitng framework is yet underinvestigated.

Thus, the present paper has two main aims: first to analyze the compliance of extracting organizations toward the International Integrated Reporting and then to investigate which type of social-environmental information is disclosing such organizations. To achieve the proposed aims, a qualitative approach in two steps was performed: analyzing the level of compliance of European extracting organizations' integrated reports toward the International Integrated Reporting Framework (IIRF) based on the Framework proposed by Zhou et al. (2017). The second step is to analyze to what extent are extracting sector companies, in particular, those from the European region, disclosing information on their integrated report about their activity, with a specific focus on social and environmental issues, as classified by Hackston and Milne (1996) and Dong (2010), divided into categories positive, negative and neutral, with the compliance toward the IIRF.

The sample of organizations has been gathered from the IIRC official database for the European zone (examples.integratedreporting.org); considering this a preliminary research, the present paper focuses on 15 organizations incorporate by the IIRC database under the region "Europe." The reports are collected from the official sites of the undertakings; content analysis is pursued to obtain information and classified through MAXQDA, a software for the qualitative analysis.

The following research sets the ground for further qualitative studies in the sphere of IR.

The present paper unfolds as follows: the second section provides a brief overview of relevant literature on extracting companies and social and environment disclosures and the concept of Integrated Reporting, the third section outlines the methodology employed to pursue the present research, the fourth section provide the results of the study and conclusions are made in the last section. 


\section{Literature Review}

Environmental awareness has been growing worldwide, resulting in countries' regulations (e.g., Paris Agreement, 2015, United Nations Climate Change). While for organizations, regulation happens in different countries. The most noticeable regulation appeared in South-African, in the Johannesburg Stock Exchange (JSE) with the release of the KING I code in 1994, followed by King II 2002 and in 2009 King III and finally when the KING IV was released in 2016. These regulations aimed to direct companies listed on JSE to more sustainable environmental, social and economic performances. At the same time, the regulations gave birth to the Integrated Reporting (IR), which later became a global movement known today all over the world, but still voluntarily, under the supervision of the IIRC. In addition, other regulations recently appeared inside the European region through the European Directive on non-financial information 2014/95/EU, entering into force in 2017 (2014/95/EU), to regulate the increasing volume of non-financial reports.

But, whether regulations strived to appear on the international level, multinational companies and visible companies have seen a noticeable spreading of sustainability reporting practices (Cho, 2015). The possibility to respond to stakeholder increased requirements through the publication of the Corporate Social Responsibility (CSR) report and Sustainability Report (SR) brought wide dissemination of such reports (Kolk, 2001; Kolk, 2003). As the stakeholder expectations can be satisfied by organizations' activity exposed in CSR reports, SR appears to improve employee satisfaction (Dean, 2003), as well as community satisfaction (Gray, 2001; Dean, 2003) and consumer opinion (Verschoor, 2006).

Furthermore, undertakings belonging to the extractive sector, such as mining and oil \& gas sectors (Guenther, 2007), has the highest reporting rate compared to other industries (Halme and Huse, 1997); mainly due to their activities impact on the environment (Ali \& O'Faircheallaigh, 2007) extracting undertakings are responding to social pressure through the issuance of CSR and SR.

To this extent, mining and oil \& gas sectors are developing their SR faster than other sectors (Halme and Huse, 1997), attracting academics' interests, which analyzed reports belonging to extracting companies.

In particular, academics demonstrate an increase in the number of annual reports, in the case of South-African mining industries, from 1999 to 2002 (de Villiers \& van Staden, 2006) and development in sustainability reports for what concerns forms, comprehensiveness in the case of oil \& gas industries (Perez, 2009). Other scholars analyzed trends and issues in the mining sector, outlining an increasing sophistication of information disclosed and inhomogeneous level of maturity in the report's contents. Also, the author developed a classification of "leaders" and "laggards" (Jenkins \& Yakovela, 2006).

Furthermore, academics analyzed the content of sustainability reports in the oil \& gas industry in the case of the Australian oil \& gas sector, outlining different aspects disclosing a high quantity of information for social and environmental matters, including employees' safety and health programs. In contrast, the author outlines the lack of quantitative data for readers about their outcomes (Dong, 2010).

Moreover, authors try to offer a framework for sustainable development of mining companies with the extent to standardize corporate reports in line with Global Reporting Initiative (GRI) requirements (Azapagic, 2004); while, others demonstrate 
CSR is likely to address critical environmental challenges (Frynas, 2009) while does not address sufficiently to governance issues and community development (Frynas, 2009; Frynas, 2010).

Based on the lacks mentioned above, a new type of corporate reports appeared among the years following the evolution of the stakeholder requirements, beginning from $1997 \mathrm{GRI}$ attracted the attention of multinational and national companies and scholars; during the years, plenty of studies examined the compliance level of corporate social report and SR, based on GRI guidelines, in different countries such as Australia (Guthrie \& Farneti, 2008), Japan (Suzuki \& Tanimoto, 2005), North America (Vigneau et al., 2015), Greece (Skouloudis et al., 2009), Romania (Berinde \& Andreescu, 2015), Hungary (Demeny, 2015) and Sweden (Hedberg and von Malmborg, 2003).

In particular, a relatively new report appeared on the international horizon which aims to "Enhance accountability and stewardship for the broad base of capitals (...) and promote understanding of their interdependencies" (IIRC, 2013; p.2), spreading from the South African experience the: "Integrated Reporting" (Eccles and Krusz 2010; Solomon and Maroun, 2012; Churet and Eccles, 2014). IR can be considered "the best way to communicate the company's overall performance to stakeholders" (Sierra-Garcia, 2015; p. 287).

IR is recognized to be the evolution of the SR (Mio \& Fasan, 2016), and although traditional reports are based on GRI guidelines, issued the first time in 1997 and recently updated, usually disclose information about social, environmental, and governance information in a disconnected manner, without giving stakeholder the clear picture of the entity (Solomon and Maroun, 2012; Marx and Mohammadali, 2014; de Villiers et al., 2017). Other authors consider that "companies are expected to achieve integration of sustainability and governance information within the annual report. Such integration is deemed essential if businesses are to embed stakeholder accountability into the heart of their operations in a meaningful way" (Maroun, 2012; p. 2016). However, Flower (2015) provided a significant critique to the movement, which considers IIRC abandoned its stimulation of sustainability accounting exchanging toward investors' needs rather than social needs.

Furthermore, authors have been focusing on the level of compliance of IR reporters toward the IIRF. Wild and van Staden (2013) analyzed a sample of 58 organizations issuing IR included in the IIRC database in 2013, outlining that early adopters, in general, failed to comply with the guiding principle of conciseness; still, authors are demonstrating that in South Africa on a sample of 40 companies listed in JSE are not in line with the requirement of the IIRF (Marx \& Mohammadali-Haji, 2014).

On the other hand, other authors outlined a change after the regulation of IR comparing annual reports from 2009-2010 to 2011-2012, information disclosed in reports increased after the regulation are: human, social and relational, natural and intellectual capital (Setia et al., 2015).

Sofian and Dumitru (2017) investigated a small sample belonging to the financial sector, including only eight European companies, for 2015; authors find that each sampled company disclosed content related to the strategic objectives and strategies to achieve them achieved the maximum level of compliance; while the governance category obtained the lowest compliance. 
In particular, studies regarding IR in the case of extracting organizations studies are scarce. However, a first attempt has been made in the Nigerian oil \& gas industry, demonstrating that Nigerian companies are disclosing information in a non-integrated way duplicating the info over the report and disclosed in a distorted form (Ayoola \& Olasanmi, 2013).

In this vein, Lai et al. (2016) focused on the influence of ESG disclosure level, firm size, leverage, profitability and environmental sensitivity on IR adoption. The sample used was composed of companies that were members of the IIRC pilot programme at the end of March 2013. However, they had to eliminate a total of 33 organisations that were not listed and did not have available ESG data. The authors, in order to demonstrate if IR adoption was a response to bad ratings, applied a logistic regression model using panel data for 2009-2011. Their results demonstrated that IR adoption is not used in order to repair bad sustainability ratings, as organisations adopting IR did not have lower ESG disclosure than non-adopters.

Moreover, Lai et al. (2016) focused on the influence of ESG disclosure level, firm size, leverage, profitability and environmental sensitivity on IR adoption. The sample used was composed of companies that were members of the IIRC pilot programme at the end of March 2013. However, they had to eliminate a total of 33 organisations that were not listed and did not have available ESG data. The authors, in order to demonstrate if IR adoption was a response to bad ratings, applied a logistic regression model using panel data for 2009-2011. Their results demonstrated that IR adoption is not used in order to repair bad sustainability ratings, as organisations adopting IR did not have lower ESG disclosure than nonadopters. Furthermore, García-Sánchez et al. (2019), using a sample of 956 companies, investigated the effects of managerial discretion in munificent contexts and the board of directors' strength. The results demonstrated that IR adoption is not associated with the munificent context, while the strength of the board and investor protection levels moderate the relationship between munificence and IR adoption (García-Sánchez et al., 2019).

As mentioned in the introduction, based on the authors' knowledge, there are only few qualitative studies focused on the oil and gas sector.

Thus, as outlined above, this research proposes an exploratory qualitative analysis about the information disclosed in the IR of oil \& gas companies members of the IIRC database to assess which types of data are being disclosed to the stakeholder and if the compliance toward the IIRF can be related to higher disclosure of qualitative information.

\section{Theoretical Framework}

The paper ground its theoretical Framework on the Legitimacy theory, which is "important in analyzing the relationships between organizations and their environments. Legitimacy provides a linkage between the organizational and societal levels of analysis. Legitimacy and social norms and values constrain the actions taken by individual organizations" (Pfeffer \& Dowling, 1975; p. 131).

In particular, Lindblom (1994) describes four strategies by which companies can gain legitimacy in their environment; first, organizations should try to keep upto-date information regarding performances and activities for its stakeholder; then, influencing their perceptions without changing their behavior. As a third move, 
companies can try to manipulate stakeholder's perception moving their attention toward favorable facts; fourth, organizations can try to shape and influence the external expectations of their performance (Guthrie et al., 2006).

According to Guthrie (2006), the existence of a "social contract" between the organization and the environment in which it operates sets the ground for the existence of legitimacy theory.

Moreover, several authors demonstrate how environmental and social disclosures are relevant for organizations to maintain their legitimacy (Hakston \& Milne, 1996; Guthrie et al., 2006; Dong, 2010; Garcia-Sanchez, 2013; Setia et al., 2015).

Thus, since the IR movement is still adopted voluntarily, besides South Africa, the information analyzed in the present research refers to the social and environmental aspects; legitimacy theory has been considered the ideal Framework for this paper.

\section{Methodology}

\subsection{Sample Composition}

The research is based on a sample of 15 companies involved in the oil \& gas and mining sector, gathered from the official database of the IIRC for the European region. Reports are collected from the official site of the organizations for the year 2019, as all organizations have reports available on their sites for the mentioned year. Reports are considered for their high credibility (Guthrie \& Parker, 1989; Willmshurst \& Frost, 2000).

Companies included in the present exploratory study belongs to the extracting sector and are presented below:

\begin{tabular}{|c|c|c|c|c|c|c|}
\hline Country & $\begin{array}{l}\text { Total } \\
\text { Assets } \\
(€)\end{array}$ & $\begin{array}{c}\text { Total } \\
\text { Revenue } \\
(€)\end{array}$ & $\begin{array}{c}\text { Net } \\
\text { Income } \\
(€)\end{array}$ & $\begin{array}{c}\text { Total } \\
\text { Employees } \\
\text { (\#) }\end{array}$ & $\begin{array}{c}\mathbf{N}^{\circ} \text { of } \\
\text { Companie } \\
\mathbf{S}\end{array}$ & \begin{tabular}{|c|} 
State- \\
Owned \\
Enterprises
\end{tabular} \\
\hline Italy & 58.100 & 58.263 & -603 & 36.369 & 2 & 2 \\
\hline Poland & 12.001 & 9.195 & -770 & 23.154 & 2 & 2 \\
\hline Russia & 35.712 & 67.717 & 2.457 & 295.800 & 1 & 1 \\
\hline Spain & 9.182 & 1.188 & 417 & 1.337 & 1 & - \\
\hline Sweden & 5.627 & 4.261 & 448 & 5.477 & 1 & - \\
\hline Switzerland & 118.520 & 138.282 & 1.247 & 154.832 & 1 & - \\
\hline UK & 513.531 & 247.691 & -435 & 187.185 & 6 & - \\
\hline Ukraine $^{1}$ & 214.816 & 58.770 & 686 & 74.765 & 1 & 1 \\
\hline Total & 968.844 & 587.090 & 3.834 & 782.798 & 15 & 6 \\
\hline
\end{tabular}

Table 4.1: Sample's financial and ownership data from Thomson Reuters EIKON, for 2016

\footnotetext{
${ }^{1}$ Data for Ukraine's company have been collected from the official report of the organization, as data are unavailable on Thomson Reuters EIKON;
} 
The IIRC Database included one organization headquartered in Mexico in the European region. However, as the present study concerns European organizations, the Mexican company has been removed from the sample, obtaining a final sample of 15 organizations.

\subsection{Research Analysis}

The study of the report has been pursued through content analysis which is: "a research technique for making replicable and valid inferences from texts (or other meaningful matter) to the contexts of their use" (Krippendorff, 1980; p. 18). As the primary aim of the paper is to study the level of compliance, the mentioned methodology has been used mainly for similar studies that aimed to analyze the compliance of IR and the risk disclosure in South Africa (Marx and Mohammadali Haji, 2014; Setia et al., 2015; Enslin et al., 2015). Also, for research about corporate social responsibility and environmental disclosure (Kilian, 2014) and other empirical studies (Guse et al., 2016; Matuszak and Rózanska, 2017; Venturelli et al., 2017).

To measure the level of compliance toward the IIRF, the reports have been manually analyzed employing the Framework given by Zhou et al. (2017). In this vein, a dichotomous coding system has been applied, with the attribution of scores for the presence (1) and absence (0) (Guse et al., 2016; Venturelli et al., 2017) per 8 categories which includes 31 elements of the IIRF given in the Zhou et al. (2017) framework.

Coding Framework based on Zhou et al. (2017)

\begin{tabular}{|c|c|c|c|}
\hline \multirow[b]{2}{*}{ Category } & \multirow[b]{2}{*}{ Elements } & \multicolumn{2}{|c|}{ Scoring Schemes } \\
\hline & & $\begin{array}{l}\text { Minimum } \\
\text { Score }\end{array}$ & $\begin{array}{l}\text { Maximum } \\
\text { Score }\end{array}$ \\
\hline \multirow{5}{*}{$\begin{array}{l}\text { Organizational } \\
\text { overview and } \\
\text { operating context }\end{array}$} & Reporting boundary & 0 & 1 \\
\hline & Mission and value & 0 & 1 \\
\hline & Business overview & 0 & 1 \\
\hline & Operational Context & 0 & 1 \\
\hline & Summary Statistics & 0 & 1 \\
\hline \multirow{4}{*}{ Governance } & Governance Structure & 0 & 1 \\
\hline & Governance Strategy & 0 & 1 \\
\hline & Remuneration and Performance & 0 & 1 \\
\hline & Governance and Others & 0 & 1 \\
\hline \multirow{3}{*}{ Risks Opportunities } & Risks & 0 & 1 \\
\hline & Opportunities & 0 & 1 \\
\hline & Strategic Objectives & 0 & 1 \\
\hline \multirow{4}{*}{$\begin{array}{c}\text { Strategy and } \\
\text { Resource Allocation }\end{array}$} & Links Between strategy and & & \\
\hline & Other Elements & 0 & 1 \\
\hline & Competitive Advantage & 0 & 1 \\
\hline & Stakeholder Consultations & 0 & 1 \\
\hline \multirow[b]{2}{*}{ Business Model } & Business Model Description & 0 & 1 \\
\hline & $\begin{array}{c}\text { Links between Business Model and } \\
\text { Others }\end{array}$ & 0 & 1 \\
\hline
\end{tabular}




\begin{tabular}{|c|c|c|c|}
\hline \multirow[b]{2}{*}{ Category } & \multirow[b]{2}{*}{ Elements } & \multicolumn{2}{|c|}{ Scoring Schemes } \\
\hline & & $\begin{array}{l}\text { Minimum } \\
\text { Score }\end{array}$ & $\begin{array}{l}\text { Maximum } \\
\text { Score }\end{array}$ \\
\hline & Stakeholder Depenceniesc & 0 & 1 \\
\hline & KPIs against Strategy & 0 & 1 \\
\hline & Explanation of KPls & 0 & 1 \\
\hline & Stakeholder Relationship & 0 & 1 \\
\hline \multirow{4}{*}{$\begin{array}{c}\text { Performance } \\
\text { and } \\
\text { Outcomes }\end{array}$} & $\begin{array}{c}\text { Past, Current, and Future } \\
\text { Performance }\end{array}$ & 0 & 1 \\
\hline & $\begin{array}{c}\text { Financial Implications of } \\
\text { Other Capitals }\end{array}$ & 0 & 1 \\
\hline & Supply Chain Performance & 0 & 1 \\
\hline & $\begin{array}{c}\text { The quality of Quantitative } \\
\text { Indicators }\end{array}$ & 0 & 1 \\
\hline \multirow{4}{*}{ Future Outlook } & Anticipated Changes & 0 & 1 \\
\hline & Potential Changes & 0 & 1 \\
\hline & Estimates & 0 & 1 \\
\hline & Conciseness and Link & 0 & 1 \\
\hline \multirow[t]{2}{*}{ Other Elements } & Materiality Determination Process & 0 & 1 \\
\hline & The Board Sign-Off & 0 & 1 \\
\hline
\end{tabular}

Table 4.2: Content employed for the compliance exercise

Results per category are calculated based on the average of each element contained in the referred category. Thus, the number of elements per category does not influence the weight of the respective type. This gives an unweighted approach for the final average calculation.

Moreover, to pursue the second aim of the present study bases its analytical Framework on the previous studies of Hackston and Milne (1996) and Dong (2010).

Information is categorized as positive, neutral and harmful for the following categories: employee, environment, community, product, energy, general ${ }^{2}$.

The categories are further included in two macro-categories exposed below:

Further Categorization of Researched Sentences

Social

Employee, Community, General
Environmental

Environment, Energy, Product

Table 4.3: Categorization proposed with the extent to summarize results

\footnotetext{
${ }^{2}$ As in Dong (2010) the general category refers to corporate commitment, objectives to be socially responsible
} 
The analysis has been carried on through the adoption of MAXQDA software. Qualitative software is not new for researchers as these have been used since the 1980s and allow users to process word and pdf files, making the research of words and sentences quicker. Such software has been used for investigations regarding legitimization of negative aspects (Hahn, 2014), changes in SR in automotive industries (Sukitsch, 2015), or for empirical studies regarding approaches of organizational learning (Siebenhuner, 2007).

Therefore, after the compliance exercise, sentences have been categorized as positive, neutral, and common negative aspects resulting from the process are going to be outlined in the fourth section after statistical details regarding the findings, including categorization of common items disclosed in integrated reports, as exposed by Dong (2010).

\section{Results \& Discussion}

\subsection{Results}

Organizations analyzed in the present study are divided equally per region: western and eastern, while public ownership is prevailing among the used sample, with three organizations being public and one being private. Sample better explained below:

\section{Sample Region and Ownership Presentation}

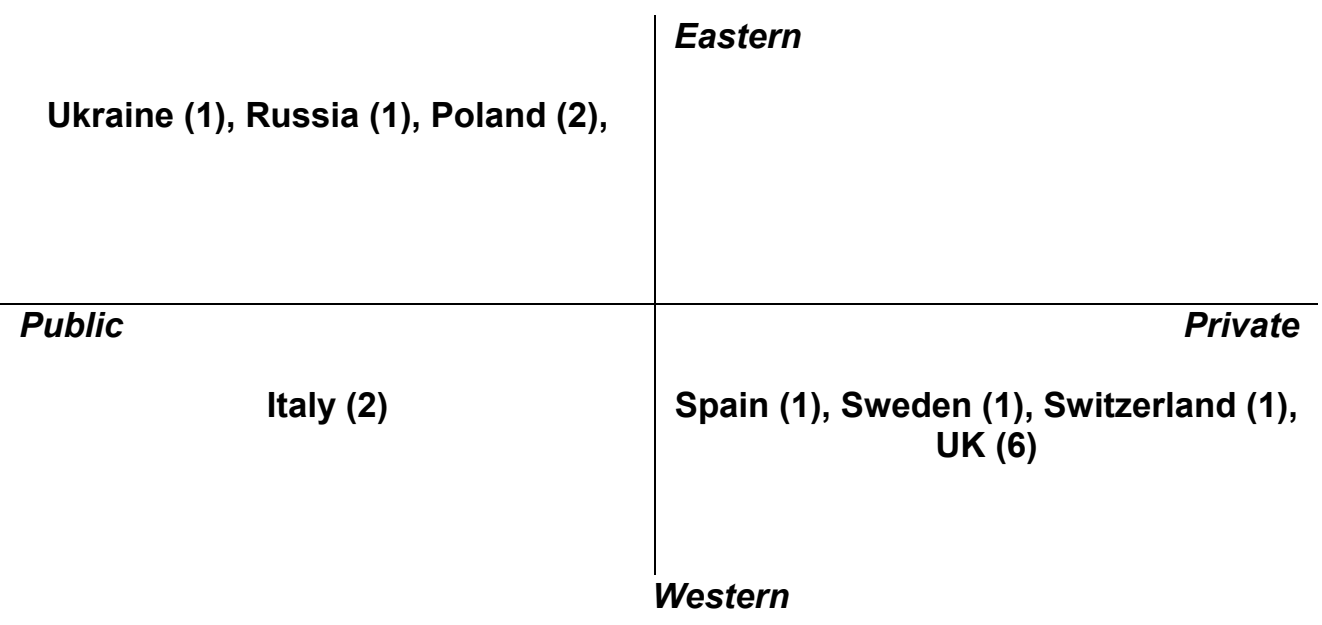

Table 5.1: sample presentation of region and ownership

Regarding ownership, the predominant public ownership is in eastern countries, ex-communist countries, being transitional economics from ex-communist countries (Tan, 2005).

The outcome of the content analysis is presented below, primarily outlining the compliance of extracting companies toward the IIRF, based on Zhou et al. (2017) and secondarily exposing the results of the qualitative content analysis, a simple descriptive statistic is provided as aggregate and as single category following Hakston and Milne (1996) and Dong (2010). 
The first exercise demonstrates, in general, a high level of compliance toward the IIRF with the following results:

\section{Compliance Analysis Results}

\begin{tabular}{|c|c|c|c|c|c|c|c|c|c|}
\hline & 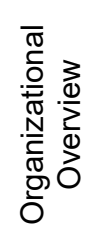 & 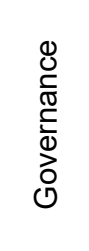 & 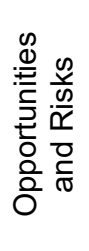 & 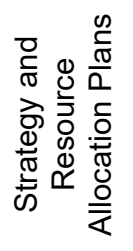 & $\begin{array}{l}\overline{0} \\
\frac{0}{0} \\
\sum_{0}^{0} \\
0 \\
0 \\
. \frac{1}{9} \\
\overline{0} \\
0\end{array}$ & 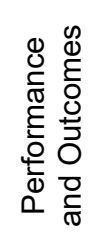 & 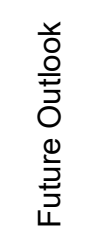 & 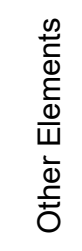 & 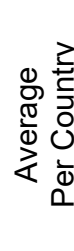 \\
\hline ITALY & 0,75 & 0,88 & 0,75 & 0,63 & 1,00 & 0,71 & 0,67 & 0,50 & 0,74 \\
\hline POLAND & 0,75 & 0,88 & 1,00 & 0,88 & 1,00 & 0,50 & 0,50 & 0,75 & 0,78 \\
\hline RUSSIA & 0,75 & 1,00 & 1,00 & 1,00 & 1,00 & 0,86 & 0,67 & 1,00 & 0,91 \\
\hline SPAIN & 0,75 & 1,00 & 1,00 & 0,75 & 1,00 & 0,86 & 0,67 & 1,00 & 0,88 \\
\hline SWEDEN & 0,75 & 1,00 & 1,00 & 0,75 & 1,00 & 0,57 & 1,00 & 1,00 & 0,88 \\
\hline SWITZERLAND & 0,75 & 1,00 & 1,00 & 0,75 & 1,00 & 0,71 & 0,33 & 1,00 & 0,82 \\
\hline UK & 0,79 & 0,96 & 1,00 & 0,54 & 0,83 & 0,71 & 0,83 & 1,00 & 0,83 \\
\hline UKRAINE & 1,00 & 1,00 & 1,00 & 0,50 & 0,67 & 0,43 & 0,67 & 0,50 & 0,72 \\
\hline $\begin{array}{l}\text { Average Per } \\
\text { Category }\end{array}$ & 0,80 & 0,95 & 0,97 & 0,69 & 0,90 & 0,68 & 0,71 & 0,88 & 0,82 \\
\hline
\end{tabular}

Table 5.2: Compliance results from the analysis based on Zhou et al. (2017), per country and category

As explained in the methodology, results have been given based on the presence or absence of the content. An example is shown below:

"[...] business model targets long-term value creation by delivering on profitability and growth, efficiency, operational excellence and handling operational risks of its businesses. Eni identifies as the main challenge of the energy industry the balance between the maximization of the access to energy and the fight against the climate change, which necessarily involves a change in the energy mix, through the reduction of carbon footprint."

Italian, Oil \& Gas entity definition of Business Model

The higher results obtained concern the "Governance," "Opportunities and Risks, "and "Business Model." Other authors have outlined similar results (Guse et al., 2016; Manes et al., 2018). Considering that the sample is composed of six State-Owned Enterprises (SOE), which are "enterprises where the state, regional governments or cities have significant control, through full, majority, or significant minority ownership" (OECD, 2011; PwC, 2015) and as these entities "have a civic responsibility to properly manage public goods, resources and/or facilities in a way 
that supports sustainable development objectives and promotes the public interest" (GRI, 2005; p.7-8); "Public sector organizations are central to the delivery of sustainable development. Every aspect of their role - from education to environmental services, and from planning to social care - shapes how people live their lives" (Birney et al., 2010, p. 3), as "accountability expectations and obligations are higher for public enterprises due to public ownership and objectives associated with the public mission" (Greiling \& Grub, 2014; p. 210). Despite the premises mentioned above, higher compliance results were expected for Italy, Poland, and Ukraine as organizations belonging to these three countries are all SOEs, but the three countries on average got the lowest results respectively 0,$74 ; 0,78 ; 0,72$.

The analyzed sample disclosed a number of 2949 coded sentences, including all categories, with a maximum of 1286 coded sentences in the environment category and a minimum of 1 regarding general references to the corporate commitment of being socially responsible.

General Descriptive Statistics

\begin{tabular}{lc}
\hline & Number of sentences \\
\hline Total & 2.949 \\
Average & 368 \\
Min & 131 \\
Max & 1.286 \\
\hline
\end{tabular}

Table 5.3: quantity of sentences disclosed by sample companies, per country

The majority of sentences recognized mostly come from UK organizations, while the minimum recognized comes from Switzerland. Further on, to present results clearer, below exposed coded sentences per category obtained per country, including total per category studied and the average of the references.

\section{References per Country}

\begin{tabular}{|c|c|c|c|c|c|c|c|c|c|c|}
\hline Categories & UK & Sweden & Poland & Ukraine & Russia & Switzerland & Italy & Spain & $\begin{array}{c}\text { Total } \\
\text { Coded } \\
\text { Sentences } \\
\end{array}$ & $\begin{array}{c}\text { Average } \\
\text { Coded } \\
\text { Sentences }\end{array}$ \\
\hline $\begin{array}{l}\text { Communityl } \\
\text { Negative }\end{array}$ & 3 & 0 & 0 & 1 & 0 & 4 & 2 & 0 & 10 & 1 \\
\hline $\begin{array}{l}\text { Communityl } \\
\text { Neutral }\end{array}$ & 14 & & 0 & 7 & 0 & 4 & 2 & 2 & 29 & 4 \\
\hline $\begin{array}{l}\text { Communityl } \\
\text { Positive }\end{array}$ & 95 & 21 & 9 & 12 & 0 & 11 & 14 & 15 & 177 & 22 \\
\hline $\begin{array}{l}\text { Total } \\
\text { Community }\end{array}$ & 112 & 21 & 9 & 20 & 0 & 19 & 18 & 17 & 216 & 27 \\
\hline $\begin{array}{l}\text { Employees। } \\
\text { Negative }\end{array}$ & 15 & 1 & 1 & 2 & 0 & 0 & 2 & 0 & 21 & 3 \\
\hline $\begin{array}{l}\text { Employees। } \\
\text { Neutral }\end{array}$ & 110 & 17 & 12 & 9 & 16 & 15 & 17 & 5 & 201 & 25 \\
\hline $\begin{array}{l}\text { Employees। } \\
\text { Positive }\end{array}$ & 236 & 45 & 115 & 45 & 63 & 15 & 13 & 40 & 572 & 72 \\
\hline Total Employees & 361 & 63 & 128 & 56 & 79 & 30 & 32 & 45 & 794 & 99 \\
\hline
\end{tabular}




\begin{tabular}{|c|c|c|c|c|c|c|c|c|c|c|}
\hline Categories & UK & Sweden & Poland & Ukraine & Russia & Switzerland & Italy & Spain & $\begin{array}{c}\text { Total } \\
\text { Coded } \\
\text { Sentences } \\
\end{array}$ & $\begin{array}{c}\text { Average } \\
\text { Coded } \\
\text { Sentences } \\
\end{array}$ \\
\hline EnergylNegative & 11 & 1 & 2 & 8 & 3 & 0 & 2 & 0 & 27 & 3 \\
\hline EnergylNeutral & 95 & 11 & 2 & 23 & 6 & 12 & 39 & 9 & 197 & 25 \\
\hline EnergylPositive & 174 & 30 & 74 & 42 & 22 & 29 & 45 & 39 & 455 & 57 \\
\hline Total Energy & 280 & 42 & 78 & 73 & 31 & 41 & 86 & 48 & 679 & 85 \\
\hline $\begin{array}{l}\text { Environmentl } \\
\text { Negative }\end{array}$ & 22 & 0 & 0 & 0 & 0 & 0 & 9 & 0 & 31 & 4 \\
\hline $\begin{array}{l}\text { Environmentl } \\
\text { Neutral }\end{array}$ & 92 & 8 & 7 & 6 & 5 & 8 & 72 & 14 & 212 & 27 \\
\hline $\begin{array}{l}\text { Environmentl } \\
\text { Positive }\end{array}$ & 238 & 45 & 160 & 43 & 50 & 14 & 60 & 38 & 648 & 81 \\
\hline $\begin{array}{l}\text { Total } \\
\text { Environment }\end{array}$ & 352 & 53 & 167 & 49 & 55 & 22 & 141 & 52 & 891 & 111 \\
\hline GenerallNegative & 2 & 0 & 0 & 0 & 0 & 0 & 0 & 0 & 2 & 0 \\
\hline GenerallNeutral & 5 & 0 & 0 & 0 & 0 & 0 & 2 & 1 & 8 & 1 \\
\hline GenerallPositive & 33 & 2 & 21 & 1 & 6 & 3 & 1 & 12 & 79 & 10 \\
\hline Total General & 40 & 2 & 21 & 1 & 6 & 3 & 3 & 13 & 89 & 11 \\
\hline Product|Negative & 12 & 1 & 0 & 1 & 2 & 1 & 1 & 2 & 20 & 3 \\
\hline Product|Neutral & 68 & 9 & 1 & 4 & 7 & 8 & 5 & 4 & 106 & 13 \\
\hline ProductlPositive & 61 & 11 & 26 & 1 & 24 & 7 & 6 & 18 & 154 & 19 \\
\hline Total Product & 141 & 21 & 27 & 6 & 33 & 16 & 12 & 24 & 280 & 35 \\
\hline $\begin{array}{l}\text { Total Coded } \\
\text { Sentences } \\
\text { per Country }\end{array}$ & $\begin{array}{c}128 \\
6\end{array}$ & 202 & 430 & 205 & 204 & 131 & 292 & 199 & 2949 & 655 \\
\hline $\begin{array}{l}\text { Average Coded } \\
\text { Sentence per } \\
\text { Organization } \\
\text { per Country }\end{array}$ & 214 & 202 & 215 & 205 & 204 & 131 & 146 & 199 & 190 & 190 \\
\hline
\end{tabular}

\section{Table 5.4: quantity of sentences disclosed by sample companies}

Few examples of coded sentences are given below to demonstrate how the selection has been made:

"The extent and cost of future environmental restoration, remediation and abatement programs are inherently difficult to estimate..."

\section{Environmental/Negative Statement}

"Community investments are our contributions to, and financial support of, the broader communities in the regions where we operate."

Community/Neutral Statement 
"In 2016, 788 employees of the Company improved their housing conditions through a long-term mortgage lending program."

\section{Employees/Positive Statement}

Poland obtained the highest number of references per organization differentiating with one reference more than the UK, which has the highest number of organizations in the sample. In contrast, Switzerland obtained the lowest number of references, with one organization obtained 131 references.

Negative sentences obtained a low score in all the analyzed categories, which demonstrate that companies are not inclined to disclosed information about negative aspects of their activity; confirming that "most environmental reports have a high propensity to disclose favorable information, such as environmental management efforts, innovation, and development of new products, environmental targets and environmental commitments, rather than negative information" (Dong, 2010; p. 110). Most of the negative aspects concern environmental disaster incurred during the financial year of reporting and refer to the damages, losses, fines, and further contribution to reestablish the environment. While dominant sentences were positive, they were disclosed in all the categories.

In particular, being extracting organizations operating in a sensible sector of activity, the category which obtained the highest positive references is the one related to the environment, with 891 references similar results have been received by Dong (2010), who considered that organizations operating in Australian oil \& gas in the sector are seeking to modify the view of their reputation by society; confirming other authors that obtained similar results (Hackston and Milne, 1996; Deegan and Gordon, 1996; Guthrie et al., 2008), this means that these organizations are respecting the "social contract" signed with the stakeholder so trying to legitimize their activity.

Moreover, the second category with the highest references belongs to employees, with 97 fewer references in comparison with environmental, Dong (2010) obtained similar results having employees in the first place with more references and second environment; however, the present study confirms noticeable attention given by these organization toward its employees, proved by the presence of different references of employees training, health care, holidays programs and long term mortgage for employees as also outlined by Hakston and Milne (1996).

Unfortunately, evidence from the analysis demonstrates that for state-owned organizations, one of the categories with the lowest results in general and community is strictly related to the organization's activity in their working environment with society.

Furthermore, a comparison between western and eastern organizations comes naturally, and the insights provided by the analysis demonstrate that eastern companies disclose more positive information than western companies. While negative and neutral aspects are disclosed more in western companies rather than eastern organizations. A similar comparison has been attempted by comparing CSR reports from Central Eastern Europe (CEE) and western countries; findings demonstrate that in the CEE region, such reports are not widespread and rarely follow GRI guidelines (Steurer \& Konrad, 2009); on this statement, further researches are required to define whether the western company is being truly demonstrating their commitment of being socially responsible. 


\subsection{Discussion}

The compliance analysis demonstrate a fair level of disclosure in line with previous studies (Sofian \& Dumitru, 2017). Although, the analysed organizations have a better understanding of the IR framework in comparison to early adopters (Wild \& van Staden, 2013). Noteworthy to mention, is the high results obtained by all organizations in specific contents of the IR, such as: "Business Model", "Organizational Overview" and "Governance" which contribute to the communication and legitimization of the organization toward stakeholders. In this perspective, results have been higher than all the analyzed literature (Sofian \& Dumitru, 2017; Wild \& van Staden, 2013; Setia et al., 2015).

Additionally, the present research outlines similar items disclosed by organizations that emerged from the classification. As the analysis shows, all the companies in the sample disclosed positive information regarding the environmental matter related to improvements of assets, reliability of assets, energy efficiency, and ecological performance programs. At the same time, common patterns regarding employees concern employees' health and safety, a significant investment for developing new skills and competencies, including safety. Moreover, positive categories regarding community and public disclosure obtained a low score. For instance, declarations about the willingness to create a sustainable impact for the society in these organizations are operating.

Regarding negative aspects, which are hardly present in the analyzed reports, the category that obtained the highest score was environmental, due to a recent scandal regarding oil extraction that affected two UK organizations and trials. Negative aspects have been generally disclosed by western organizations demonstrating a higher degree of transparency. Other remarkable negative aspects are related to the product category. Due to the instability of the raw materials markets presented in the reports, companies disclosed information about decreasing revenue due to market volatility. However, the organization rarely disclosed negative news, as also outlined by Hahn (2014).

Furthermore, the present research correlates the results from the compliance exercise with the Framework proposed by Dong (2011). Thus, the correlation seems forced. IR contains requirements regarding the aspects presented in Dong's Framework. Therefore, the correlation between the compliance analysis and the study based on Dong (2011) framework does not offer relevant results, as the countries with the highest compliance results (Russia, UK, Spain, Sweden) have a similar number of references as the country with the lowest compliance result (Ukraine).

\section{Compliance Results and Average References}

\begin{tabular}{lcccc}
\hline & $\begin{array}{c}\text { Average Per } \\
\text { Country }\end{array}$ & $\begin{array}{c}\text { Average Reference } \\
\text { per Organization }\end{array}$ & $\begin{array}{c}\text { Average } \\
\text { Reference Social }\end{array}$ & $\begin{array}{c}\text { Average Reference } \\
\text { Environmental }\end{array}$ \\
\hline Italy & 0,74 & 146 & 27 & 120 \\
Poland & 0,78 & 215 & 79 & 136 \\
Russia & 0,91 & 204 & 85 & 119 \\
Spain & 0,88 & 199 & 75 & 124 \\
Sweden & 0,88 & 202 & 86 & 116 \\
Switzerland & 0,82 & 131 & 52 & 79 \\
Uk & 0,83 & 214 & 86 & 129 \\
Ukraine & 0,72 & 205 & 77 & 128 \\
\hline Total & $\mathbf{0 , 8 2}$ & $\mathbf{1 9 0}$ & $\mathbf{7 1}$ & $\mathbf{1 2 0}$ \\
Average & $\mathbf{1 9 0}$ & & & \\
\hline
\end{tabular}

Table 5.5: level of compliance and $n .^{\circ}$ of sentences disclosed by the analyzed companies 
Moreover, Switzerland, with a compliance level of 0,88 , obtained the lowest results in the second analysis with only 131 , closer to Italy with a compliance score of 0,74 than Russia, which received the highest compliance result of 0,91 .

\section{Conclusion}

In conclusion, the present exploratory study demonstrates that extracting organizations have, on average, high compliance toward the IIRF, demonstrating a low level of compliance by SOEs, and a higher level of compliance is provided by western organizations rather than eastern companies. Moreover, organizations disclose the most information regarding environmental and employee matters, providing an increased number of information about the mentioned categories. However, two categories are ignored by the sample, general and community; even if the environmental impact of their activity is significant (Ali \& O'Faircheallaigh, 2007), extracting organizations are not disclosing information concerning their activities for the communities in which are involved, as they are doing with environmental and employees; the same results has been outlined by Dong (2010).

Although different reports have been analyzed from the study of Dong (2010), comparing the results, there is an increased number of references for what concern negative aspects of the organizations' activity, which requires further research similar to Hahn (2014) with the extent to examine how these organizations are legitimizing their negative aspects.

The paper contributes to the existing literature as it focuses on only one sector of activity on a longitudinal horizon adding to the literature information related to the compliance evolution toward the IIRF in the case of Oil \& Gas organizaitons.

As a practical implication, extracting companies need to improve their disclosure regarding their activities as corporate citizens or their commitment to being socially responsible. While eastern organizations are recommended to disclose adverse information about their activities as happen in western companies.

Findings can be considered consistent with prior studies on other corporate reports and in different areas such as New Zealand (Hakston \& Milne, 1996) and Australia (Dong, 2010), although the present analysis provides a slightly different result from the mentioned studies.

To this extent, further studies must be conducted in the sphere of qualitative analysis of Integrated Report considering that until now, studies on IR are related to compliance toward the IIRF (Wild \& van Staden, 2013; Marx \& MohammadaliHaji, 2014; Setia et al., 2015; Sofian \& Dumitru 2017).

Significant limitations of the present study rely upon the restricted sample that comprehends only 15 organizations as further research guidelines are recommended to consider more organizations, different geographical areas with the extent to analyze similar behavior in other regions.

As further development of the present study, a comparison between countries member of the European Union vs. Non-EU members. To analyze to what extent the non-financial information is developing inside the $\mathrm{EU}$ as it began to regulate non-financial information flux through the EU Directive 2014/95/EU, which have been already regulated in England, Netherland, and Spain. Moreover, other sectors can be included for similar and further qualitative studies, as Integrated Reported has not yet been studied under a similar lens. 
Finally, the present study represents the first attempt in qualitative analysis of IR; further qualitative analysis research must be conducted in the Integrated Reporting horizon.

Acknowledgements: This work was possible with the financial support of the Operational Programme Human Capital 2014-2020, under the project POCU 123793, entitled 'Researcher, future entrepreneur - New Generation'.

\section{References}

Ali, S. H., \& O'Faircheallaigh, C. S. (2007). Introduction: Extractive industries, environmental performance and corporate social responsibility. Greener Management International, 52, 5-16.

Ayoola, T. J., \& Olasanmi, O. O. (2013). Business case for integrated reporting in the Nigerian oil and gas sector. Issues in Social and Environmental Accounting, $7(1), 30-54$.

Azapagic, A. (2004). Developing a framework for sustainable development indicators for the mining and minerals industry. Journal of cleaner production, 12(6), 639-662.

Berinde, M., \& Andreescu, N. A. (2015). Reporting Corporate Social Responsibility According to GRI Standards. The Annals of the University of Oradea, 17.

Bewley, K., \& Li, Y. (2000). Disclosure of environmental information by Canadian manufacturing companies: a voluntary disclosure perspective. In Advances in Environmental Accounting \& Management (pp. 201-226). Emerald Group Publishing Limited.

Birney, A., Clarkson, H., Madden, P., Porritt, J., \& Tuxworth, B. (2010). Stepping up: A framework for public sector leadership on sustainability. In London: Forum for the Future (pp. 1-7).

Cho, C. H., Laine, M., Roberts, R. W., \& Rodrigue, M. (2015). Organized hypocrisy, organizational façades, and sustainability reporting. Accounting, Organizations and Society, 40, 78-94.

Christiansen, H. (2011). The Size and Composition of the SOE Sector in OECD Countries. OECD Publishing, 80-98.

Churet, C., \& Eccles, R. G. (2014). Integrated reporting, quality of management, and financial performance. Journal of Applied Corporate Finance, 26(1), 5664.

Cowell, S. J., Wehrmeyer, W., Argust, P. W., \& Robertson, J. G. S. (1999). Sustainability and the primary extraction industries: theories and practice. Resources policy, 25(4), 277-286.

Cuganesan, S., Ward, L., \& Guthrie, J. (2007). Social and Environmental Reporting: The Australian Food and Beverage Industry.

De Villiers, C., \& Van Staden, C. J. (2006). Can less environmental disclosure have a legitimizing effect? Evidence from Africa. Accounting, organizations and society, 31(8), 763-781.

Dean, D.H. (2003), Consumer perception of corporate donations: effects of company reputation for social responsibility and type of donation, Journal of Advertising, Vol. 32 No. 4, pp. 91-102. 
Deegan, C., \& Gordon, B. (1996). A study of the environmental disclosure practices of Australian corporations. Accounting and business research, 26(3), 187-199.

Demény, A. (2015). The Hungarian Sustainability Reports In The Light Of The Global Reporting Initiative (GRI). Challenges in economic and technological development, 34.

Dong, S., \& Burritt, R. (2010). Cross-sectional benchmarking of social and environmental reporting practice in the australian oil and gas industry. Sustainable Development, 18(2), 108-118.

Dowling, J., \& Pfeffer, J. (1975). Organizational legitimacy: Social values and organizational behavior. Pacific sociological review, 18(1), 122-136.

Eccles, R. G., \& Krzus, M. P. (2010). One report: Integrated reporting for a sustainable strategy. John Wiley \& Sons.

Eccles, R. G., \& Saltzman, D. (2011). Achieving sustainability through integrated reporting. Stanf Soc Innov Rev Summer, 59.

Enslin, Z., Bruwer, W., \& Viljoen, C. (2015). Enhancing risk-related disclosure in South Africa: a study on guidelines and current practices. Journal of Economic and Financial Sciences, 8(1), 261-280.

European Council- Council of the European Union. (2017). http://www.consilium.europa.eu/en/policies/climate-change/internationalagreements-climate-action/ (accessed on $29^{\text {th }}$ March 2018).

Flower, J. (2015). The international integrated reporting council: a story of failure. Critical Perspectives on Accounting, 27, 1-17.

Frias-Aceituno, J. V., Rodriguez-Ariza, L., \& Garcia-Sanchez, I. M. (2013). The role of the board in the dissemination of integrated corporate social reporting. Corporate Social Responsibility and Environmental Management, 20(4), 219-233.

Frynas, J. G. (2005). The false developmental promise of corporate social responsibility: Evidence from multinational oil companies. International affairs, 81(3), 581-598.

Frynas, J. G. (2009). Corporate social responsibility in the oil and gas sector. Journal of World Energy Law \& Business, 2(3), 178-195.

Frynas, J. G. (2010). Corporate social responsibility and societal governance: Lessons from transparency in the oil and gas sector. Journal of business ethics, 93(2), 163-179.

García-Sánchez, I. M., Aibar-Guzmán, B., Aibar-Guzmán, C., \& Azevedo, T. C. (2020). CEO ability and sustainability disclosures: The mediating effect of corporate social responsibility performance. Corporate Social Responsibility and Environmental Management, 27(4), 1565-1577.

Global Reporting Initiative, G. R. I. (2005). Public Sector Sustainability reporting.

Gray, R. (2001), "Responsibility up the agenda", Marketing London, p. 3 May.

Gray, R., Kouhy, R., \& Lavers, S. (1995). Corporate social and environmental reporting: a review of the literature and a longitudinal study of UK disclosure. Accounting, Auditing \& Accountability Journal, 8(2), 47-77.

Greiling, D., \& Grüb, B. (2014). Sustainability reporting in Austrian and German local public enterprises. Journal of Economic Policy Reform, 17(3), 209-223.

Guenther, E., Hoppe, H., \& Poser, C. (2007). Environmental Corporate Social Responsibility of Firms in the Mining and Oil and Gas Industries: Current Status Quo of Reporting Following GRI Guidelines. Greener Management International, (53). 
Guse, R. G., Almaan, A., Circa, C., \& Dumitru, M. (2016). The role of the stakeholders in the institutionalization of the CSR reporting in Romania. Accounting and Management Information Systems, 15(2), 304.

Guthrie J, Parker L. (1989). Corporate social reporting: a rebuttal of legitimacy theory. Accounting and Business Research 19(76): 343- 352.

Guthrie, J., \& Farneti, F. (2008). GRI sustainability reporting by Australian public sector organizations. Public Money and management, 28(6), 361-366.

Guthrie, J., Petty, R., \& Ricceri, F. (2006). The voluntary reporting of intellectual capital: Comparing evidence from Hong Kong and Australia. Journal of Intellectual Capital, 7(2), 254-271.

Hackston, D., \& Milne, M. J. (1996). Some determinants of social and environmental disclosures in New Zealand companies. Accounting, Auditing \& Accountability Journal, 9(1), 77-108.

Hahn, R., \& Lülfs, R. (2014). Legitimizing negative aspects in GRI-oriented sustainability reporting: A qualitative analysis of corporate disclosure strategies. Journal of business ethics, 123(3), 401-420.

Halme, M., \& Huse, M. (1997). The influence of corporate governance, industry and country factors on environmental reporting. Scandinavian journal of Management, 13(2), 137-157.

Hedberg, C. J., \& Von Malmborg, F. (2003). The global reporting initiative and corporate sustainability reporting in Swedish companies. Corporate social responsibility and environmental management, 10(3), 153-164.

Jenkins, H., \& Yakovleva, N. (2006). Corporate social responsibility in the mining industry: Exploring trends in social and environmental disclosure. Journal of cleaner production, 14(3-4), 271-284.

Kolk, A. (2003). Trends in sustainability reporting by the Fortune Global 250. Business strategy and the environment, 12(5), 279-291.

Kolk, A., \& Levy, D. (2001). Winds of Change: Corporate Strategy, Climate change and Oil Multinationals. European Management Journal, 19(5), 501-509.

Krippendorff, K. (1980) Content analysis: an introduction to its methodology. Sage Publications, Inc.

Lai, A., Melloni, G., \& Stacchezzini, R. (2016). Corporate sustainable development: is 'integrated reporting'a legitimation strategy?. Business Strategy and the Environment, 25(3), 165-177.

Madsen, P. M. (2009). Does corporate investment drive a "race to the bottom" in environmental protection? A reexamination of the effect of environmental regulation on investment. Academy of Management Journal, 52(6), 1297-1318.

Manes-Rossi, F., Tiron-Tudor, A., Nicolò, G., \& Zanellato, G. (2018). Ensuring More Sustainable Reporting in Europe Using Non-Financial Disclosure-De Facto and De Jure Evidence. Sustainability, 10(4), 1162.

Marx, B., \& Mohammadali-Haji, A. (2014). Emerging trends in reporting: an analysis of integrated reporting practices by South African top 40 listed companies. Journal of Economic and Financial Sciences, 7(1), 231-250.

Matuszak, Ł., \& Różańska, E. (2017). CSR Disclosure in Polish-Listed Companies in the Light of Directive 2014/95/EU Requirements: Empirical Evidence. Sustainability, 9(12), 2304.

Mio, C. (Ed.). (2016). Integrated Reporting: A New Accounting Disclosure. Springer. 
Neuman, W. L. (2013). Social research methods: Qualitative and quantitative approaches. Pearson education.

Pachauri, R. K., \& Meyer, L. (2014). Climate change 2014 Synthesis Report-Summary for Policymakers.

Paternostro, S.. The Connectivity of Information for the Integrated Reporting, in Busco, C. A. (2016). Integrated Reporting. Springer.

Perez, F., \& Sanchez, L. E. (2009). Assessing the evolution of sustainability reporting in the mining sector. Environmental management, 43(6), 949-961.

Setia, N., Abhayawansa, S., Joshi, M., \& Huynh, A. V. (2015). Integrated reporting in South Africa: some initial evidence. Sustainability Accounting, Management and Policy Journal, 6(3), 397-424.

Shehata, N. F. (2014). Theories and Determinants of Voluntary Disclosure. Accounting and Finance Research, 3(1), 18-26.

Siebenhüner, B., \& Arnold, M. (2007). Organizational learning to manage sustainable development. Business strategy and the environment, 16(5), 339-353.

Skouloudis, Antonis, and Konstantinos I. Evangelinos. "Sustainability reporting in Greece: are we there yet?." Environmental Quality Management 19.1 (2009): 4360.

Sofian, I., \& Dumitru, M. (2017). The Compliance of the Integrated Reports Issued by European Financial Companies with the International Integrated Reporting Framework. Sustainability, 9(8), 1319.

Solomon, J., \& Maroun, W. (2012). Integrated reporting: the influence of King III on social, ethical and environmental reporting.

Spence, D. B. (2011). Corporate social responsibility in the oil and gas industry: The importance of reputational risk. Chi.-Kent L. Rev., 86, 59.

Steurer, R., \& Konrad, A. (2009). Business-society relations in Central-Eastern and Western Europe: How those who lead in sustainability reporting bridge the gap in corporate (social) responsibility. Scandinavian Journal of Management, 25(1), 2336.

Sturesson, J., Mclntyre, S., \& Jones, N. C. (2015). State-Owned Enterprises: Catalysts for Public Value Creation. PWC. com, 1-48.

Sukitsch, M., Engert, S., \& Baumgartner, R. J. (2015). The implementation of corporate sustainability in the European automotive industry: An analysis of sustainability reports. Sustainability, 7(9), 11504-11531.

Tan, J. (2005). Venturing in turbulent water: A historical perspective of economic reform and entrepreneurial transformation. Journal of Business Venturing, 20(5), 689-704.

Tan, J. (2005). Venturing in turbulent water: A historical perspective of economic reform and entrepreneurial transformation. Journal of Business Venturing, 20(5), 689-704.

Tanimoto, K., \& Suzuki, K. (2005). Corporate social responsibility in Japan: Analyzing the participating companies in global reporting initiative.

Tiron-Tudor, A., Nistor, C. S., Ştefănescu, C. A., \& Zanellato, G. (2019). Encompassing Non-Financial Reporting in a Coercive Framework for Enhancing Social Responsibility: Romanian Listed Companies'case. Amfiteatru Economic, 21(52), 590-606. 
Venturelli, A., Caputo, F., Cosma, S., Leopizzi, R., \& Pizzi, S. (2017). Directive 2014/95/EU: Are Italian Companies Already Compliant?, Sustainability, 9(8), 1385.

Verschoor, C.C. (2006), "Consumers consider the importance of corporate social responsibility", Strategic Finance, Vol. 88 No. 2, pp. 20-2.

Vigneau, L., Humphreys, M., \& Moon, J. (2015). How do firms comply with international sustainability standards? Processes and consequences of adopting the global reporting initiative. Journal of Business Ethics, 131(2), 469-486.

Villiers, C., Venter, E. R., \& Hsiao, P. C. K. (2017). Integrated reporting: background, measurement issues, approaches and an agenda for future research. Accounting \& Finance, 57(4), 937-959.

Wild, S., \& van Staden, C. (2013, July). Integrated reporting: initial analysis of early reporters-an institutional theory approach. In 7th Asia Pacific Interdisciplinary Accounting Research Conference (pp. 26-28).

Wilmshurst TD, Frost GR. (2000). Corporate environmental reporting: a test of legitimacy theory. Accounting, Auditing and Accountability Journal 13(1): 10-26.

Yongvanich, K., \& Guthrie, J. (2005, March). Extended performance reporting: an examination of the Australian mining industry. In Accounting Forum (Vol. 29, No. 1, pp. 103-119). Elsevier.

Zhou, S., Simnett, R., \& Green, W. (2017). Does integrated reporting matter to the capital market?. Abacus, 53(1), 94-132. 